\title{
PENGARUH SENAM TERHADAP KADAR GULA DARAH PADA PENDERITA DIABETES MELLITUS TIPE 2 DI RSUD PURI HUSADA TEMBILAHAN TAHUN 2016
}

\author{
Ridha Hidayat \\ Dosen FIK Universitas Pahlawan Tuanku Tambusai, Riau, Indonesia \\ ridhahidayat@yahoo.co.id
}

\begin{abstract}
ABSTRAK
Diabetes mellitus merupakan penyakit yang berjangka panjang maka bila diabaikan komplikasi penyakit diabetes mellitus dapat menyerang seluruh anggota tubuh yang di akibatkan dari kadar gula darah yang tidak terkontrol pada pengidap diabetes. Dampak dari Diabetes Mellitus ini dapat berupa gangguan makrovaskuler maupun mikrovaskuler seperti penyakit jantung, penyakit vaskuler perifer, gagal ginjal, kerusakan syaraf dan kebutaan. Penelitian ini bertujuan untuk mengetahui pengaruh senam diabetes terhadap kadar gula darah pada penderita diabetes mellitus tipe 2 di RSUD Puri Husada Tembilahan Tahun 2016. Penelitian bersifat eksperimen dengan desain eksperimen semu. Populasi penelitian sebanyak 107 orang, dengan sampel sebanyak 20 orang diambil dengan teknik purposive sampling. Analisi data menggunakan uji willcoxon dengan hasilpenelitianmenunjukkan ada pengaruh senam diabetes terhadap kadar gula darah pada penderita diabetes mellitus tipe 2 dengan nilai $p$ value 0,000 . Disarankanbagiselingkungan RSUD Puri Husada agar selalu memberikan penyuluhanpenyuluhan terhadap penyakit diabetes mellitus dan instruktur senam diabetes agar lebih memperhatikan penderita diabetes dengan menambah waktu latihan terhadap penderita diabetes mellitus dalam melakukan kegiatan senam diabetes.
\end{abstract}

Kata kunci : Senam Diabetes, Kadar Gula Darah, Diabetes Mellitus Tipe 2 Kepustakaan : 2006-2016

\section{PENDAHULUAN}

Diabetes mellitusmerupakan penyakit yang berjangka panjang maka bila diabaikan komplikasi penyakit diabetes mellitus dapat menyerang seluruh anggota tubuh yang di akibatkan dari kadar gula darah yang tidak terkontrol pada pengidap diabetes, tindakan pengendalian diabetes untuk mencegah terjadinya komplikasi sangatlah diperlukan khususnya menjaga tingkat gula darah sedekat mungkin dengan normal. Akan tetapi kadar gula darah yang benar-benar normal sulit untuk dipertahankan, hal ini disebabkan karena pasien kurang disiplin dalam menjalankan diet atau tidak mampu mengurangi jumlah kalori makanannya (Soegondo, 2015)

Meningkatnya prevelensi diabetes mellitus tipe 2 di beberapa Negara berkembang akibat peningkatan kemakmuran di Negara bersangkutan akhir-akhir ini banyak disoroti. Peningkatan perkapita dan 
perkembangan gaya hidup terutama di kota-kota besar, menyebabkan peningkatan penyakit degeneratif, salah satunya adalah penyakit diabetes mellitus tipe 2. Diabetes mellitus tipe 2 merupakan salah satu masalah kesehatan yang berdampak produktifitas dan dapat menurunkan sumber daya manusia, penyakit ini tidak hanya berpengaruh secara individu tetapi system kesehatan suatu negara (Sudoyo, 2007)

Kontrol diabetes mellitus tipe 2 yang buruk dapat mengakibatkan hiperglikemia dalam jangka panjang, yang menjadi pemicu beberapa komplikasi yang serius baik makrovaskular maupun mikrovaskular seperti penyakit jantung, penyakit vaskuler perifer, gagal ginjal, kerusakan saraf dan kebutaan. Banyaknya komplikasi yang mengiringi penyakit diabetes mellitus tipe 2 telah memberikan kontribusi terjadinya perubahan fisik, psikologis maupun sosial (Anani, 2012)

Hari Diabetes Sedunia (World

Diabetes Day, WDD) diperingati untuk meningkatkan perhatian terhadap diabetes yang kejadiannya terus meningkat di dunia, diprakarsai oleh International Diabetes Federation (IDF) dan World Health Organization (WHO). WDD diperingati sejak tahun 1991 setiap tanggal 14 November. Estimasi terakhir IDF, terdapat 382 juta orang yang hidup dengan diabetes di dunia pada tahun 2013. Pada tahun 2035 jumlah tersebut diperkirakan akan meningkat menjadi 592 juta orang. Diperkirakan dari 382 juta orang tersebut, 175 juta diantaranya belum terdiagnosa, sehingga terancam berkembang progresif menjadi komplikasi tanpa disadari dan tanpa pencegahan (Arisman, 2010)
Berdasarkan Riset Kesehatan Dasar (Riskesdas) pada tahun 2013 di Indonesia didapatkan bahwa proporsi diabetes mellitus tipe 2 sebesar 6,9\%, TGT ( Toleransi Gula Terganggu ) sebesar 29,9\% dan GDP ( Gula Darah Puasa ) terganggu sebesar $36,6 \%$, terjadi peningkatan sebesar 1,5-2,3\% dibandingkan pada tahun 2007

Indragiri Hilir memilki prevelensi diabetes mellitus tipe 2yang terdiagnosa oleh petugas kesehatan sebesar $0,7 \%$ dan yang terdiagnosa dan dengan gejala sebesar 0,7\% sejalan dengan itu data Dinas Kesehatan Provinsi Riau tahun 2013 menunjukan bahwa prevalensi diabetes mellitus tipe 2, baik berdasarkan diagnosis maupun diagnosis dan gejala, secara rerata di tingkat Provinsi Riau didapatkan angka lebih tinggi daripada angka nasional. Penyakit ini tersebar di seluruh Kabupaten dan Kota di Riau, penderita diabetes mellitustipe 2 di Indragiri Hilir didominasi oleh perempuan yaitu $1,1 \%$ dengan rentang umur 55-64 tahun dengan 4,6 $\%$.

Prevelesi penderitadiabetes mellitus tipe 2wilayah kerja RSUD Puri Husadapada tahun 2013 sebanyak 340 orang, terjadi peningkatan pada tahun 2014 menjadi 379 orang dan pada tahun 2015 meningkat menjadi 421 orang dengan jumlah kunjungan tiap bulan diperkirakan sebanyak 90kunjungan , pada tahun 2016 data menyebutkan bahwa bulan Januari ada 107 orang penderita diabetes mellitus tipe 2 yang berkunjung di RSUD Puri Husada, dengan kata lain terjadi peningkatan jumlah kunjungan penderita diabetes mellitus tipe 2 di RSUD Puri Husada. 
Dalam hal perencanaan diet sebenarnya tidak ada makanan yang dilarang untuk pasien diabetes mellitus tipe 2 tapi hanya dibatasi saja sesuai kebutuhan kalori penderita tersebut. Menu makanan juga sama dengan menu keluarga dirumah. Maka yang menjadi kunci keberhasilan pengelolaan penyakit diabetes mellitus tipe 2 adalah makanlah sesuai dengan kebutuhan kalori. Kedua adalah latihan (olahraga) merupakan salah satu cara untuk mengontrol kadar glukosa dalam darah sebab dengan olahraga dapat meningkatkan pemakaian glukosa oleh otot yang aktif. Cara ketiga adalah obat-obatan, pada penderta diabetes mellitus tipe 2obatobatan bersifat seumur hidup untuk dapat mengendalikan kadar gula darah agar selalu terkontrol dengan baik dan cara terakhir adalah penyuluhan, penyuluhan yang berkelanjutan dan membimbing untuk penderita diabetes mellitus tipe 2 sangat berguna sehingga pasien diabetes mellitustipe 2 menjadi mandiri, misalnya penyuluhan tentang apa itu penyakit diabetes mellitus tipe 2,bagaimana upaya pencegahan agar tidak sampai terjadi komplikasi yang tidak diinginkan, serta bagaimana mengatasi penyakit diabetes mellitus tipe 2 yang sudah berkomplikasi agar tidak semakin parah (Titin, 2010).Aktifitas atau pergerakan tubuh sering diabaikan oleh setiap penderita diabetes mellitus tipe 2, hal ini dapat disebabkan oleh berbagai faktor seperti keterbatasan waktu untuk melakukan senam (latihan fisik) oleh karena pekerjaan, usia yang tidak memungkinkan, dan minat yang kurang untuk melakukan aktifitas fisik, serta kurangnya pengetahuan akan pentingnya aktifitas fisik (senam).

Pada zaman sekarang ini, banyak penderita diabetes mellitus tipe 2 yang lebih fokus dan hanya mengutamakan pada penanganan diet dan mengkonsumsi obat-obatan, padahal penanganan diet yang teratur belum menjamin akan terkontrolnya kadar glukosa dalam darah, akan tetapi hal ini harus diseimbangi dengan latihan fisik yang sesuai. Sebab jika penderita diabetes mellitus tipe 2 tidak melakukan aktifitas fisik maka metabolisme otot yang terjadi hanya sedikit, sehingga pemakaian glukosa dalam darah berkurang, hal ini dapat menyebabkan penumpukan glukosa dalam darah, sehingga kadar glukosa dalam darah tinggi.

Keseimbangan antara diet, latihan, obat-obatan dan penyuluhan sangatlah penting, sebab dengan diet yang sesuai dengan kebutuhan, disertai dengan latihan yang teratur akan membantu pengambilan glukosa dalam darah oleh otot-otot yang aktif pada saat berolahraga. Hal ini berarti latihan fisik ini salah satu faktor yang harus dilakukan oleh para penderita diabetes mellitus tipe 2 agar tidak terjadi komplikasi yang lebih berat (Novitasari, 2012)

Pada penderita diabetes mellitus tipe 1, latihan fisik kurang bermanfaat dalam penurunan kadar glukosa darah, sebab pada diabetes melitus tipe I kadar insulinnya rendah oleh karena ketidakmampuan pankreas dalam memproduksi insulin, sehingga penderita diabetes melitus tipe 1 mudah mengalami hipoglikemi selama dan segera setelah olahraga atau latihan jasmani (Ilyas, 2009).

Pada penderita diabetes mellitus tipe 2, latihan jasmani 
memiliki peran utama dalam pengaturan kadar glukosa darah. Pada penderita diabetes mellitus tipe 2 , produksi insulin tidak terganggu, tetapi karena respon reseptor pada sel terhadap insulin (resistensi) masih kurang, maka insulin tidak dapat membantu transfer glukosa kedalam sel. Pada saat berolahraga, keadaan permeabilitas membran terhadap glukosa meningkat pada otot yang berkontraksi sehingga resistensi insulin berkurang, dengan kata lain sensitivitas insulin meningkat (Anggriyana, 2010).

Aktifitas fisik merupakan cara yang sangat penting untuk dilakukan oleh penderita diabetes mellitus tipe 2 terutama dalam menangani peningkatan glukosa dalam darah. Salah satu latihan yang dianjurkan adalah senam diabetes. Senam diabetes adalah senam fisik yang dirancang menurut usia dan status fisik dan merupakan bagian dari pengobatan diabetes mellitus tipe 2 . Senam diabetes dibuat oleh para spesialis yang berkaitan dengan diabetes, diantaranya adalah rehabilitasi medis, penyakit dalam, olahraga kesehatan, serta ahli gizi dan sanggar senam (Sumarni, 2008).

Senam tersebut khusus dirancang untuk pasien diabetes mellitus tipe 2 dan gerakan senam diabetes tidak jauh beda dari senam kesehatan jasmani (SKJ) yaitu pemanasan, gerakan inti, pendinginan. Senam diabetes dilakukan secara teratur 3-5 kali dalam seminggu dengan durasi 30-60 menit. Gerakan yang mudah dilakukan, serta ekonomis (Ilyas, 2009).

Dari hasil penelitian (Indriati, 1990) mengatakan bahwa adanya pengaruh latihan fisik dengan turunnya kadar glukosa darah, hal ini dibuktikan dengan penurunan kadar glukosa darah rata-rata $60,767 \mathrm{mg}$ pada penelitian yang dia lakukan pada penderita diabetes mellitus tipe 1 dan 2

Manfaat dari senam diabetes yaitu Mengontrol gula darah, terutama pada diabetes mellitus tipe 2 yang mengikuti olahraga teratur,Menghambat dan memperbaiki faktor resiko penyakit kardiovaskuler yang banyak terjadi pada penderita diabetes mellitus tipe 2,Senam diabetesdapat memperbaiki profil lemak darah, dan kolesterol total, serta memperbaiki sirkulasi dan tekanan darah,Menurunkan berat badan, pengaturan olahraga secara optimal dan diet diabetes mellitustipe 2pada penderita kegemukan,Memperbaiki gejalagejala muskuloskeletal otot, tulang, sendi, serta gejala-gejala neuropati perifer seperti kesemutan, dan kebas,Mencegah terjadinya diabetes mellitus tipe 2 yang dini terutama bagi orang-orang dengan riwayat keluarga diabetes mellitus tipe 2, Mengurangi kebutuhan pemakaian obat oral dan insulin.

Strategi intervensi keperawatan komunitas dalam konteks asuhan keperawatan pada agregat diabetisi memiliki beberapa karakteristik, yaitu berfokus pada populasi baik yang sehat maupun yang berisiko menderita diabetes mellitus, beriorientasi pada peningkatan peran serta aktif dalam pengelolaan diabetes mellitus secara mandiri, berfokus pada upaya promotif dan preventif baik pencegahan primer, sekunder, dan tersier. Intervensi pendidikan kesehatan dalam pengelolaan diabetes secara mandiri di tingkat komunitas atau populasi, memiliki perhatian terhadap peningkatan derajat kesehatan pada 
semua kelompok umur terutama kelompok berisiko diabetes mellitus (Ribonson, 2008)

Dari hasil survey awal yang dilakukan peneliti tanggal 28 s.d 29 Maret 2016 di RSUD Puri Husada terdapat 10 responden, ada 5 responden diantaranya yang pernah melakukan / rutin berolahraga, 3 responden diantaranya mengetahui tentang senam diabetes, 2 responden diantaranya pernah melakukan senam diabetes.

Berdasarkan permasalahan yang telah disebutkan maka peneliti tertarik melakukan penelitian tentang "Pengaruh Senam DiabetesTerhadap Kadar Gula Darah Pada Penderita Diabetes Mellitus Tipe 2 Di RSUD Puri Husada Tembilahan Tahun 2016"

\section{Rumusan Masalah}

Berdasarkan uraian latar belakang di atas, maka permasalahan yang dapat dirumuskan oleh penulis adalah "Adakah Pengaruh Senam Terhadap Kadar Gula Darah Pada Penderita Diabetes Mellitus Tipe 2 Di RSUD Puri Husada Tembilahan Tahun 2016?"

\section{Tujuan Penelitian}

\section{Tujuan Umum}

Untuk mengetahui pengaruh senam diabetes terhadap kadar gula darah pada penderita diabetes mellitus tipe 2 di RSUD Puri Husada Tembilahan Tahun 2016

\section{Tujuan Khusus}

a. Untuk mengetahui kadar gula darah pada penderita diabetes mellitus tipe 2 sebelum melakukan senam diabetes di RSUD Puri Husada Tembilahan Tahun 2016.

b. Untuk mengetahui kadar gula darah pada penderita diabetes mellitus tipe 2 sesudah melakukan senam diabetes di
RSUD Puri Husada

Tembilahan Tahun 2016.

c. Untuk mengetahui pengaruh senam diabetes terhadap kadar gula darah pada penderita diabetes mellitus tipe 2 di RSUD Puri Husada Tembilahan Tahun 2016

\section{Manfaat Penelitian}

\section{Aspek Teoritis}

Bagi institusi pendidikan kesehatan dapat dimanfaatkan sebagai bahan masukan untuk mengembangkan ilmu pengetahuan, bagi peneliti selanjutnya dalam menyusun hipotesa baru ataupun dengan jenis penelitian yang berbeda.

\section{Aspek Praktis}

Dapat digunakan oleh
tenaga kesehatan dalam
meningkatkan
kesehatan dan diharapkan dapat
dijadikan sebagai bahan
perencanaan dan evaluasi
terhadap permasalahan yang ada.

\section{TINJAUAN KEPUSTAKAAN}

\section{Pengertian Diabetes Mellitus}

Diabetes mellitus adalah gangguan endokrin kronik dalam metabolisme glukosa. Ini akibat dari defek produksi atau kerja insulin dan dicirikan dengan metabolisme karbohidrat, protein, dan lemak secara abnormal, yang mengakibatkan hiperglikemia.

Diabetes mellitus adalah gangguan endokrin yang paling umum dan meski pun etiologi tepatnya masih tidak pasti, faktor lingkungan yang digabungkan dengan kerentanan genetik menentukan individu mana yang secara aktual mengalami sindrom 
klinis dan menentukan kapan waktu awitannya (Ernawati, 2013)

Diabetes mellitus

merupakan sekelompok kelainan heterogen yang ditandai oleh kenaikan kadar glukosa dalam darah atau hiperglikemia. Diabetes mellitus adalah suatu kumpulan gejala yang timbul pada seseorang yang disebabkan oleh karena adanya peningkatan kadar gula darah akibat kekurangan insulin baik absolut maupun relatif (Padila, 2012)

\section{Klasifikasi Diabetes Mellitus}

Klasifikasi diabetes mellitus menurut ADA (American Diabetes Association) 2009 yaitu :

a. Tipe 1, Diabetes tipe ini disebabkan karena destruksi sel beta pankreas yang bertugas menghasilkan insulin. Tipe ini menjurus ke defisiensi insulin absolut, proses destruksi ini dapat terjadi karena proses imunologik maupun idiopatik.

b. Tipe 2, tipe ini bervariasi mulai dari yang predominan resistensi insulin disertai defisiensi insulin relatif sampai yang predominan gangguan sekresi insulin bersama resistensi insulin.

c. Diabetes mellitus tipe lain :

1) Defek genetik fungsi sel beta akibat mutasi di kromosom 12 (HNF- $\alpha$ ), 7 (glukokinase), 20 (HNF- $\alpha$ ), 13 (insulin promoter factor $), \quad 17$ (HNF- $\alpha), \quad 2$ (Neuro D1)

2) Defek genetik kerja insulin : resistens insulin tipe A

3) Penyakit eksokrin pankreas : pankreatitis, trauma/pankreatektomi, fibrosis kistik

4) Endokrinopati
5) Karena obat/zat kimia : vacor, pentamidin, asam nikotinat, hormon tiroid

6) Infeksi : rubella kongenital

7) Imunologi (jarang) : antibody antireseptor insulin

8) Sindrom genetik lain

9) Diabetes kehamilan (Arisman, 2010)

\section{Insiden diabetes mellitus tipe 2}

Insidens diabetes mellitus tipe 2 tampak meningkat, dan faktor yang mungkin berhubungan dengan peningktan insidensi ini adalah faktor lingkungan. Prevalensi diabetes mellitus tipe 2 pada bangsa kulit putih berkisar antara 3-6\% dari orang dewasanya. Untuk semua kelompok usia di seluruh dunia diperkirakan $2,8 \%$ pada tahun 2000 dan diperkirakan meningkat sampai $4,4 \%$ pada tahun 2030 . Jumlah total orang mengidap diabetes tipe 2 diperkirakan meningkat dari 171 juta pada tahun 2000 menjadi 366 juta pada tahun 2020.

Biaya untuk kualitas hidup individu, ekonomi dan masyarakat telah jelas. Diabetes mellitus tipe 2 menimbulkan komplikasi serius seperti penyakit jantung, kebutaan, gagal ginjal, dan stroke serta kerusakan saraf yang menyebabkan amputasi (Wylie, 2010)

\section{Etiologi Diabetes Mellitus Tipe} 2

Melihat tendensi kenaikan prevalensi diabetes secara global terutama disebabkan oleh karena peningkatan kemakmuran suatu populasi, maka dengan demikian dapat dimengerti bila suatu saat atau lebih tepat lagi dalam kurun waktu 1 atau 2 dekade yang akan 
datang kekerapan diabetes mellitus tipe 2 di Indonesia akan meningkat dengan drastis, yang disebabkan oleh beberapa faktor :

a. Faktor keturunan (genetik)

b. Faktor kegemukan/obesitas seperti perubahan gaya hidup dari tradisional ke gaya hidup barat, makan berlebihan, hidup santai, kurang aktivitas

c. Faktor demografi seperti jumlah penduduk meningkat, urbanisasi, penduduk berumur diatas 40 tahun meningkat

d. Berkurangnya penyakit infeksi dan kurang gizi (Soegondo, 2015)

\section{Faktor Risiko Diabetes Mellitus} Tipe 2

Faktor-faktor risiko terjadinya diabetes mellitus tipe 2 menurut ADA dengan modifikasi terdiri dari :

a. Faktor risiko mayor :

1) Riwayat keluarga $D M$

2) Obesitas

3) Kurang aktivitas fisik

4) Ras/etnik

5) Sebelum teridentifikasi sebagai IFG

6) Hipertensi

7) Tidak terkontrol dan HDL

8) Riwayat DM pada kehamilan

9) Sindrom polikistik ovarium

b. Faktor risiko lainnya :

1) Faktor nutrisi

2) Konsumsi alkohol

3) Kebiasaan mendengkur

4) Faktor stress

5) Kebiasaan merokok

6) Jenis kelamin

7) Lama tidur

8) Intake zat besi

9) Konsumsi kopi dan kafein

10) Paritas

11) Intake zat besi
6. Patofisiologi Diabetes Mellitus Tipe 2

Meskipun patofisiologi diabetes mellitus bermuara pada resistensi insulin, toleransi glukosa akan tetap terjaga normal selama masih dapat dikompensasi oleh peningkatan sekresi insulin. Jadi sel beta pankreas yang masih berfungsi normal mampu menduga keparahan resistensi insulin serta mengatur sekresi insulin untuk mempertahankan kenormalan toleransi glukosa.

Kelainan utama yang tergambar pada diabetes mellitus tipe 2 berupa resistensi insulin dan penyusutan fungsi sekretorik selsel beta. Ketidakpekaan insulin dalam merespon lonjakan gula darah menyebabkan peningkatan produksi glukosa oleh hati seraya penurunan ambilan glukosa oleh jaringan. Hilangnya respon akut terhadap beban $\mathrm{KH}$ yang merupakan kelainan khas dini pada diabetes mellitus, biasanya terjadi ketika kadar gula darah puasa mencapai angka 115 $\mathrm{mg} / \mathrm{dL}$, yang terdiagnosis sebagai hiperglisemia postprandial. Fungsi sel-sel beta dipastikan susut sebanyak $75 \%$ manakala kadar gula darah puasa telah merapat ke angka $140 \mathrm{mg} / \mathrm{dL}$.

Peningkatan kadar glukosa darah dalam keadaan puasa merupakan cerminan dari pengurangan ambilan glukosa oleh jaringan. Atau petambahan glukoneogenesis. Jika kadar glukosa darah meningkat sedimikian tinggi, ginjal tidak akan mampu lagi menyerap balik glukosa yang tersaring sehingga glukosa akan tumpah ke dalam urin. Kelimpahan glukosa dalam urin ini dinamakan glukosuria. 
Ketidakpekaan insulin di sel-sel hati dan jaringan tepi, terutama otot rangka, mengakibatkan produksi glukosa oleh hati menjadi tidak terbendung, sementara ambilan dan penggunaan glukosa justru berkurang. Mekanisme terjadinya boleh jadi terkait dengan defek pengikatan reseptor insulin, pengurangan jumlah reseptor insulin, atau penurunan kemampuan insulin post-receptor. Selanjutnya, hiperglisemia ini akan menutup "keran"sekresi sembari memperpatah ketidakpekaan insulin dengan jalan "menciutkan" sistem transportasi glukosa dalam sel-sel beta dan pada jaringan pekainsulin. Pengaruh tingginya kadar glukosa darah yang berlangsung kronis dikenal sebagai tosisitas glukosa. Ketidakpekaan insulin semakin diperberat oleh peningkatan kadar asam lemak bebas dalam darah, dan berdampak lebih buruk pada kinerja sel-sel beta dalam menyekresikan insulin. Gejala terakhir ini disebut lipotoksisitas. Manifestasi diabetes mellitus tipe 2 terbagi menjadi dua bentuk. Bentuk pertama, sindrom diabetik akut, menampakkan gambar hiperglisemia, ketoasidosis dan (jika tidak diobati) kematian. Bentuk kedua, diabetik kronik, ditandai dengan mikroangiopati difus pada jaringan penyusun organ-organ vital.

Pada prinsipnya, bertambahnya keluaran glukosa hati melatarbelakangi peningkatan kadar glukosa darah puasa, sementara berkurangnya penggunaan glukosa perifer mendasari hiperglisemia postprandial(Arisman, 2011)

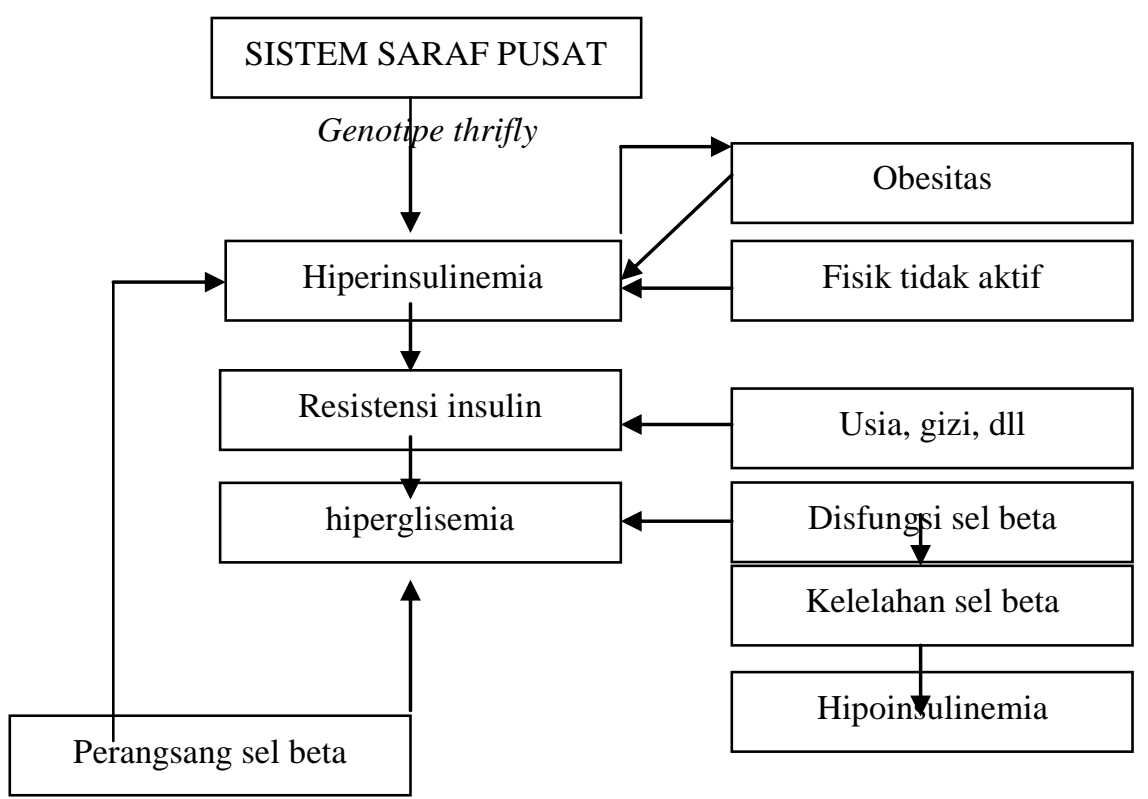




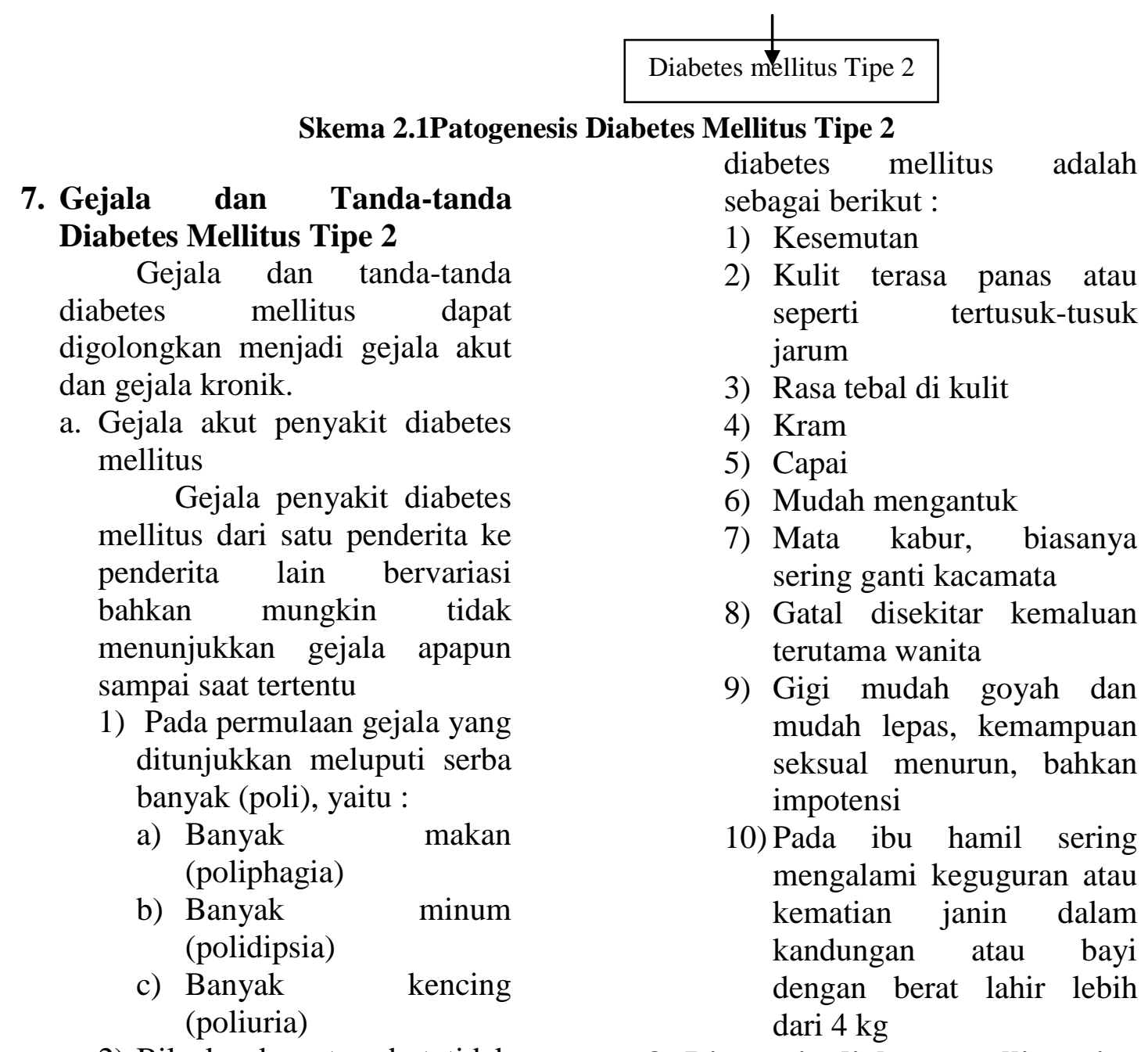

2) Bila keadaan tersebut tidak segera diobati, akan timbul gejala :
a) Banyak minum
b) Banyak kencing
c) Nafsu makan mulai berkurang / berat badan turun dengan cepat (turun 5-10 kg dalam 2-4 minggu)
d) Mudah lelah
e) Bila tidak lekas diobati, akan timbul rasa mual, bahkan penderita akan jatuh koma yang disebut dengan koma diabetik

b. Gejala kronik diabetes mellitus Gejala kronik yang sering dialami oleh penderita

\section{Diagnosis diabetes mellitus tipe} 2

Diagnosis diabetes mellitus tipe 2ditegakkan dengan mengadakan pemeriksaan kadar glukosa darah untuk penentuan diagnosis diabetes mellitus tipe 2 . Pemeriksaan glukosa darah yang dianjurkan adalah pemeriksaan glukosa secara enzimatik dengan bahan darah plasma vena. Penggunaan bahan darah utuh (whole blood), vena ataupun kapiler tetap dapat dipergunakan dengan memperhatikan angkaangka kriteria diagnostik yang berbeda sesuai pembakuan WHO, sedangkan untuk pemantauan hasil pengobatan dapat dilakukan 
dengan pemeriksaan glukosa darah kapiler.

Kriteria diagnosis diabetes mellitus menurut ADA tahun 2007 adalah sebagai berikut :

a. Gejala klasik diabetes mellitus + kadar glukosa darah sewaktu $\geq 200 \mathrm{mg} / \mathrm{dl}$ (11.1 mmol/L). Glukosa darah sewaktu merupakan hasil pemeriksaan sesaat pada suatu hari tanpa memperhatikan waktu makan terakhir. Gejala klasik adalah poliuria, polidipsia, polifagia, dan berat badan turun tanpa sebab

b. Gejala klasik diabetes mellitus + kadar glukosa darah puasa $\geq 126 \mathrm{mg} / \mathrm{dl} \quad(7.0 \mathrm{mmol} / \mathrm{L})$. Puasa adalah pasien tidak mendapat kalori sedikitnya 8 jam

c. Kadar glukosa darah 2 jam PP $\geq 200 \quad \mathrm{mg} / \mathrm{dl} \quad(11.1 \mathrm{mmol} / \mathrm{L})$ TTGO dilakukan dengan standar WHO, menggunakan beban glukosa ya $g$ setara dengan 75 gr glukosa anhidrus yang dilarutkan ke dalam air. Apabila hasil pemeriksaan tidak memenuhi kriteria normal atau diabetes mellitus, maka dapat digolongkan ke dalam kelompok TGT atau GDTP tergantung dari hasil yang diperoleh : TGT (glukosa darah plasma 2 jam setelah beban antara 140-199 mg/dl (7,8-11,0 $\mathrm{mmol} / \mathrm{L}$ ), GDPT (glukosa darah puasa antara 100-125 $\mathrm{mg} / \mathrm{dl}(5,6-6,9 \mathrm{mmol} / \mathrm{L})$

\section{Pemeriksaan Penunjang}

a. Glukosa dalam sewaktu

b. Kadar glukosa dalam puasa

c. Tes toleransi glukosa

Kadar darah sewaktu dan puasa sebagai patokan penyaring diagnosis diabetes mellitus $(\mathrm{mg} / \mathrm{dl})$

Tabel 2.1

Kadar Darah Sewaktu

\begin{tabular}{|l|c|c|c|}
\hline & $\begin{array}{c}\text { Bukan Diabetes } \\
\text { Mellitus }\end{array}$ & $\begin{array}{c}\text { Belum Pasti } \\
\text { Diabetes Mellitus }\end{array}$ & Diabetes Mellitus \\
\hline $\begin{array}{l}\text { Kadar glukosa } \\
\text { darah sewaktu }\end{array}$ & & & \\
- Plasma vena & $<100$ & $100-200$ & $>200$ \\
- Darah kapiler & $<80$ & $80-200$ & $>200$ \\
\hline Kadar glukosa & & & \\
darah puasa & $<110$ & $110-120$ & $>126$ \\
- Plasma vena & $<90$ & $90-110$ & $>110$ \\
\hline
\end{tabular}


Kriteria diagnostik WHO untuk diabetes mellitus sedikitnya 2 kali pemeriksaan:

a. Glukosa plasma sewaktu $>200$ $\mathrm{mg} / \mathrm{dl}(11,1 \mathrm{mmol} / \mathrm{L})$

b. Glukosa plasma puasa $>140$ $\mathrm{mg} / \mathrm{dl}(7,8 \mathrm{mmol} / \mathrm{L})$

c. Glukosa plasma dari sampel yang diambil 2 jam kemudian sesudah mengkonsumsi $75 \mathrm{~kg}$ karbohidrat (2 jam post prandial (pp) >200 mg/dl (Padila, 2012)

10. Patogenesis Komplikasi Pada Diabetes Mellitus Tipe 2

Banyak mekanisme yang mengaitkan hiperglikemia dengan komplikasi jangka panjang diabetes. Saat ini terdapat 2 mekanisme yang dianggap penting :

a. Glikosilasi non enzimatik

Glikosilasi non enzimatik adalah proses perlekatan glukosa secara kimiawi ke gugus amino bebas pada protein tanpa bantuan enzim. Produk glikosilasi kolagen dan protein lain yang berumur panjang dalam jaringan interstisium dan dinding pembuluh darah mengalami serangkaian tata ulang kimiawi (yang berlangsung lambat) untuk membentuk irreversible advanced glycosylation end products (AGE), yang terus menumpuk di dinding pembuluh. AGE memiliki sejumlah sifat kimiawi dan biologik yang berpotensi patogenik :

1) Pembentukan AGE pada protein, seperti kolagen, menyebabkan pembentukan ikatan silang diantara berbagai polipeptida, hal ini kemudian dapat menyebabkan tertangkapnya protein interstisium dan plasmayang tidak terglikosilasi.

Terperangkapnya

lipoprotein densitas rendah (LDL) sebagai contoh, menyebabkan protein ini tidak dapat keluar dari dinding pembuluh dan mendorong pengendapan kolesterol di intima sehingga terjadi percepatan aterogenesis. AGE juga dapat mempengaruhi struktur dan fungsi kapiler, termasuk kapiler di glomerulus ginjal, yang mengalami penebalan membrane basal dan menjadi bocor.

2) AGE berikatan dengan reseptor pada banyak tipe sel, seperti sel endotel, monosit,makrofag, limfosit, dan sel mesangium. Pengikatan ini menimbulkan beragam aktivitas biologis, termasuk emigrasi monosit, pengeluaran sitokin dan faktor pertumbuhan dari makrofag, peningkatan permeabilitas endotel, dan peningkatan proliferasi fibroblast serta sel otot polos serta sintesis matriks ekstrasel. Semua efek ini berpotensi menyebabkan komplikasi diabetes.

b. Hiperglikemia intrasel disertai gangguan pada jalur-jalur poliol

Hiperglikemia intrasel disertai gangguan pada jalurjalur poliol merupakan mekanisme utama kedua yang diperkirakan berperan dalam timbulnya komplikasi yang 
berkaitan

dengan

hiperglikemia. Pada sebagian jaringan yang tidak memerlukan insulin untuk transpor glukosa (misal : saraf, lensa, ginjal, pembuluh darah) hiperglikemia menyebabkan peningkatan glukosa intrasel yang kemudian dimetabolisme oleh aldosa reduktase menjadi sorbitol, suatu poliol dan akhirnya menjadi fruktosa. Perubahan ini menimbulkan beberapa efek yang tidak diinginkan. Penimbunan sorbitol dan fruktosa menyebabkan peningkatan osmolaritas intrasel dan influks air dan akhirnya menyebabkan cedera sel osmotik (Kumar, 2007)

\section{Kadar Gula Darah}

Istilah gula darah menurut ilmu kedokteran mengacu pada tingkat glukosa yang ada dalam darah. Tingkat glukosa di dalam tubuh telah diatur dengan ketat, karena glukosa atau gula darah yang mengalir di dalam darah merupakan sumber energi yang utama untuk sel di dalam tubuh manusia.

Pada umumnya glukosa atau gula darah manusia bertahan dalam batas yang sempit dalam sehari yakni $4-8 \mathrm{mmol} / \mathrm{I}$ atau 70 - $150 \mathrm{mg} / \mathrm{dL}$. Namun tingkat ini bisa saja meningkat pada saat kita makan, biasanya pada level yang terendah saat pagi hari sebelum sarapan/makan pagi.

Banyak orang yang tidak mengetahui kisaran kadar gula darah ideal, untuk mengetahui hal itu dapat merujuk pada ukuran gula darah yang normal menurut WHO. Supaya dapat memiliki acuan yang terpercaya dan jelas untuk menjaga kadar gula dalam tubuh agar tidak naik dan turun.

a. Ketika orang sedang melakukan puasa kadar gula normal dalam tubuh adalah 4 $7 \mathrm{mmol} / \mathrm{I}$ atau setara dengan 72 $-126 \mathrm{mg} / \mathrm{dL}$

b. Sedangkan setelah kurang lebih 90 menit kita makan, kadar gula darah yang normal dalam tubuh adalah $10 \mathrm{mmol} / \mathrm{I}$ atau setara $180 \mathrm{mg} / \mathrm{dL}$

c. Pada malam hari kadar gula darah yang normal dalam tubuh kita adalah $8 \mathrm{mmol} / \mathrm{I}$ atau setara $144 \mathrm{mg} / \mathrm{dL}$

\section{Pengendalian Kadar Gula} Darah

Terdapat 4 pilar pengendalian kadar gula darah pada penderita diabetes mellitus tipe 2, yakni :

a. Penyuluhan (edukasi)

Melakukan pendidikan

kesehatan menjadi kewajiban bagi seluruh tenaga kesehatan untuk membuka mata dan pengetahuan masyarakat mengenai semua hal yang berkaitan dengan kesehatan. Begitupun dengan diabetes mellitus, penderitanya atau diabetis harus mengetahui dan mengerti apa yang dimaksud dengan diabetes mellitus tipe 2 , apa yang menyebabkan penyakit tersebut, kemudian komplikasi seperti apa yang terjadi jika penderitanya bersikap acuh tak acuh dalam melakukan pengobatan. Pendidikan kesehatan bisa dilakukan lewat media apapun, secara langsung face to face dengan melakukan seminar atau penyuluhan, membagikan bulletin khusus kesehatan secara percuma-cuma atau jika 
diabetis memiliki komunitas khusus bisa dengan cara mudah yakni seluler to seluler dari handphone ke handphone sehingga berita kesehatan lebih cepat tersebar.

b. Kebutuhan kalori

Diabetis,
menjadi kewajiban $\begin{array}{r}\text { untuk } \\ \text { mengontrol setiap asuhan } \\ \text { makanan yang }\end{array}$ akan
dikonsumsi. Mengontrol disini
bukanlah melarang tetapi
harus lebih cermat memilih
setiap kandungan gizi yang
terdapat dalam makanan agar
pankreas yang mengalami
gangguan tidak kesakitan
untuk menghasilkan insulin.
Sulitnya untuk menyebarkan
makanan ke dalam sel, jumlah
insulin yang dihasilkan sedikit
sedangkan memakan makanan
yang memiliki kandungan gula
tinggi.
Mulailah dengan berkonsultasi kepada dokter atau ahli kesehatan diabetes mellitus untuk menyusun pola diet. Dietpun bukan semata mogok makan dengan tidak memakan apapun tetapi diet yang penuh dengan nilai gizi. Jumlahnya seimbang untuk memenuhi kebutuhan nutrisi, jenisnya sesuai dengan zat gizi yang harus diperoleh.

3. Olahraga (senam)

Singkatnya senam
diabetes (olahraga) baik
dilakukan untuk membantu
pengendalian gula darah dan
berat badan, prinsip senam
diabetes yaitu terus-menerus,
berirama, berselang,
meningkat dan daha tahan.

4. Obat-obatan
Pemberian obat dilakukan untuk mengatasi kekurangan produksi insulin serta menurunkan resistensi insulin. Obat-obatan disini dibagi menjadi dua, yakni oral dan injeksi sesuai dengan tipe diabetes mellitus tipe 2 yang di derita

Untuk diabetes melitus tipe 2 : pertama, obat yang digunakan untuk membantu produksi insulin yang kurang adalah obat yang dapat merangsang pankreas untuk meningkatkan produksi insulin. Kedua, obat yang digunakan untuk memperbaiki hambatan terhadap kerja insulin atau resistensi insulin.

Sudah jelas bukan diantara ke 4 pilar itu berhubungan satu sama lain, jika salah satu tidak dilaksanakan maka hasil optimal pengendalian diabetes mellitus tipe 2 susah untuk dicapai. Semuanya harus dijalankan dengan bersamaan agar saling membantu satu sama lain.

\section{Senam Diabetes}

Senam diabetes adalah senam fisik yang dirancang menurut usia dan status fisik dan merupakan bagian dari pengobatan diabetes mellitus tipe 2. Penggunaan olah raga dalam pengobatan diabetes mellitus tipe 2 sudah bukan hal yang baru, dan justru dipergunakan sebelum ditemukannya insulin pada tahun 1921. PERKENI (Perkumpulan Endokrinologi Indonesia) 2006 dalam laporannya mengenai mellitus mengatakan bahwa aktivitas fisik yang dirancang menurut usia dan status fisik 
merupakan bagian penting dalam pengobatan diabetes mellitus tipe 2. Senam mempunyai efek menaikkan aksi insulin di jaringan, sehingga kebutuhan akan insulin menurun (Soegondo, 2015)

\section{Manfaat Senam Diabetes}

Adapun manfaat senam diabetes antara lain :

a. Mengontrol gula darah, untuk diabetes mellitus tipe 2 senam yang teratur dapat menurunkan resistensi insulin meningkatkan sensitivitas insulin di otototot dan jaringan lain sehingga kadar gula darah mengalami perbaikan.

b. Meningkatkan kadar kolesterol baik HDL, senam teratur dapat menurunkan kadar kolesterol LDL yang dapat menyumbat arteri koroner sedangkan HDL mengumpulkan kolesterol untuk dikirimnya ke hati selanjutnya di buang.

c. Menurunkan berat badan, untuk diabetis yang memiliki kelebihan berat badan dengan olahraga dapat memperbaiki resistensi insulin, mengontol gula darah dan menghindari risiko penyakit jantung koroner.

d. Memperbaiki gejala-gejala musuloskeletal, yang dimaksud dengan gejalagejala tersebut adalah kesemutan, gatal-gatal, linu diujung jari tangan atau persendian lainnya. Dengan senam diabetes diharapkan dapat mengurangi gejalagejala tersebut karena semua anggota badan pada saat senam bergerak.

e. Memperbaiki kualitas hidup, selain meningkatkan kesegaran jasmani karena terkontrolnya sistem kardiovaskular, respirasi, gula darah. Senam diabetes pun dapat menjadi solusi menghilangkan perasaan cemas dan depresi (Novitasari, 2012)

Disamping memberikan manfaat untuk menurunkan glukosa darah dan perbaikan profil lipid, senam juga memberi manfaat untuk mencegah komplikasi mikroangiopati dan makroangiopati. Pemilihan jenis latihan bagi pasien diabetes mellitus pada dasarnya tidak berbeda dengan orang sehat. Memilih latihan yang disenangi, akan bisa menjamin keberlangsungan latihan yang teratur. Jogging, bersepeda, jalan, berenang, mendayung dan senam bisa dijadikan latihan pilihan. Macam latihan diatas mampu menjamin keberlangsungan CRIPE (Continous, Rhytmical, Interval, Progressive, Endurance training). Latihan yang terus menerus dan ritmis memang mempunyai berbagai kelebihan, antara lain mudah dilakukan, mudah dipantau intensitasnya dan memberi efek besar terhadap kebugaran dan kesehatan seseorang (Soegondo, 2015).

Hal lain yang perlu diperkatikan dalam pemilihan jenis latihan adalah keadaan penderita. Pada penderita dengan berat badan berlebih, lebih dianjurkan untuk memilih 
renang atau bersepeda agar beban pada lutut terkurangi. Sementara penderita dengan kaki yang tidak sensitif harus menghindari latihan berlarilari atau jogging dan memilih bersepeda atau berenang. Penderita retinopati proliferatif harus menghindari latihan yang berkaitan dengan valsava meneuver yang menyebabkan gangguan dan sentaka pada kepala, dan latihan dengan posisi kepala lebih rendah. Sedangkan bagi penderita dengan hipertensi harus menghindari latihan valsava dengan maneuver: latihan yang berat pada tubuh dan lengan (latihan ekstremitas bawah) lebih dianjurkan (Soegondo, 2015).

\section{PedomanProgram Latihan bagi Penderita Diabetes Melitus} Tipe 2

Pedoman program latihan bagi penderita diabetes melitus (Soegondo, 2015)

a. Jenis senam, aerobik

b. Durasi; 30-60 menit (pemanasan, inti, dan pendinginan)

Tahapan senam: masing-masing tahap senam meliputi:

a. 5-10 menit pemanasan peregangan tungkai

b. 20-30 menit latihan aerobik dengan denyut jantung pada zona target (75-80\% denyut jantung maksimal)

c. 15-20 menit latihan ringan dan peregangan untuk pendinginan

Hal-hal yang perlu di perhatikan adalah setiap program latihan, apapun macamnya harus mengandung unsur pemanasan, latihan inti dan pendinginan. Pemanasan dimaksudkan untuk mempersiapkan organ-organ tubuh beserta perangkatnya (termasuk enzim) agar mampu melakukan gerakan-gerakan dengan baik dan terhindar dari cedera. Lebih dari itu pemanasan juga dimaksudkan untuk mempersiapkan menghadapi latihan. Latihan inti disesuaikan dengan kemampuan, kemauan, keharusan dan keadaan. Latihan ini sangat spesifik, setiap kasus berbeda dan pada kasus yang sama pun satu orang dengan orang lain akan berbeda. Pendinginan dilakukan dengan cara mengurangi gerakan secara bertahap sebelum berhenti sama sekali. Merupakan suatu keharusan untuk melakukan pendinginan setelah latihan, sebab tanpa pendinginan dapat timbul rasa pusing, mual, muntah, bahkan bisa sampai pingsan. Pendinginan juga bermanfaat untuk mempercepat hilangnya rasa capai setelah latihan, sebab zat pelelah (asam laktat) akan segera kembali ke peredaran darah.

Tahap-tahap dalam melakukan senam (Soegondo, 2015) adalah sebagai berikut :

a. Peregangan (streching). Latihan ini bertujuan untuk mencegah cedera otot. Lakukan gerakan peregangan pada semua otot tubuh selama lebih kurang 5 menit.

b. Pemanasaan (warming up). Pemanasan sebaiknya dilakukan dalam gerakan lambat selama lima sampai 10 menit sehingga kecepatan 
jantung meningkat secara bertahap.

c. Latihan inti dengan kecepatan penuh (full speed). Lakukan gerakan olahraga dengan irama lebih cepat selama 20-30 menit. Ini bertujuan untuk meninglatkan kerja jantung dan paru.

d. Pendinginan (cooling down). Lakukan gerakan pendinginan dalam tempo lambat selama 5-10 menit. Regangkan semua otot untuk mencegah nyeri atau cidera.

Variasi gerakan dalam senam diabetes cukup banyak. Senam tersebut bisa mengolah semua organ tubuh manusia, mulai dari otak hingga ujung kaki. Sebab, dampak penyakit diabetes melitus menyerang seluruh tubuh. Dampak yang paling ringan adalah kesemutan, sedangkan yang terparah adalah menderita stroke. Senam dapat memperbaiki sirkulasi darah memperkuat otot-otot kecil kaki dan mencegah terjadinya kelainan bentuk kaki. Selain itu dapat meningkatkan kekuatan otot paha, betis dan juga mengatasi keterbatasan gerak sendi. Latihan senam kaki dapat dilakukan dengan posisi tidur, duduk dan berdiri dengan cara menggerakkan kaki dan sendisendi kaki.

c. Frekuensi senam: tiga sampai lima kali seminggu

d. Intensitas senam: menyesuaikan usia, kapasitas oksigen maksimal dan tingkat keparahan penyakit.

Intensitas latihan dan beratnya latihan paling tepat ditentukan dengan presentase kapasitas oksigen maksimal, namun karena pengukuran kapasitas oksigen maksimal secara langsung tidak mudah, maka digunakan jumlah denyut nadi per menit sebagai penunjuk intensitas latihan. Denyut nadi maksimal yang boleh dicapai adalah 220 di kurangi umur. Untuk menentukan denyut nadi latihan di kemukakan berbagai cara, antara lain presentase langsung dari denyut nadi maksimal, misal 50\% dari 200-umur.

\section{Gerakan Senam Diabetes}

a. Latihan pemanasan

Sebelum masuk ke dalam gerakan inti, sebaiknya lakukan pemanasan. Berikut ini tujuan pemanasan :

1) Adaptasi jantung terhadap seluruh kegiatan senam

2) Memperbaiki jaringan pembuluh darah dan otot yang telah berubah posisinya

3) Melancarkan perdarahan darah

4) Memperbaiki sistem syaraf dalam tubuh terutama bagian tulang punggung yang merupakan kumpulan jutaan syaraf

5) Melemaskan otot-otot tubuh agar bisa relaksasi

a) Gerakan 1 : badan tegap dengan sikap sempurna

b) Gerakan 2 : kaki berjinjit satu dan dua tangan disimpan dipinggang

c) Gerakan 3 :

(1) Salah satu kaki tarik ke belakang 
(2) Kepalkan kedua tangan simpan diatas dada dan pinggang

(3) Lakukan gerakan jalan ditempat dengan ayunan tangan

$$
\text { Gerakan }
$$

3

bermanfaat

menyiapkan kondisi tubuh baik secara fisiologis dan psikologis sehingga dapat melakukan senam dengan baik dan benar. Gerakan dimulai dengan kaki kanan dan hitungan jantung pada kaki kanan.

d) Gerakan 4 :

(1) Simpan tangan yang terlentang diatas dada

(2) Tundukkan kepala Gerakan 4 bermanfaat untuk mengatur nafas secara perlahan dan bertahap agar paru-paru dan jantung bekerja dengan baik selama berlatih. Gerakan dilakukan dengan jalan ditempat sementara tangan di rentangkan dari bagian samping tubuh ke atas lalu berakhir di dada sementara kepala masih dalam posisi menunduk.

e) Gerakan 5 :
(1) Satu tangan direntangkan sementara tangan yang lain disimpan di dada

(2) Kepala menoleh bergantian ke kanan dan kiri

Manfaat gerakan tersebut untuk melenturkan persendian otot bagian kiri dan kanan

f) Gerakan 6 :

(1) Kepala dimiringkan ke kanan dan ke kiri

(2) Kedua tangan disimpan dipinggang

(3) Jalan ditempat Manfaat gerakan 6 melatih dan melenturkan persendian otot kepala

g) Gerakan 7 :

(1) Langkahkan kaki ke kanan dan ke kiri 1 langkah

(2) Tangan mengepal di sisi badan

(3) Bahu diangkat dan diputar ke belakang Manfaat gerakan 7 untuk melenturkan persendian otot bahu, pinggang bagian atas dan dada

h) Gerakan 8 :

(1) Langkahkan kaki ke kanan dan ke kiri 2 langkah

(2) Tangan mengepal di sisi badan

(3) Bahu diangkat bergantian ke kanan dan ke kiri

Manfaat gerakan 8 untuk melenturkan persendian otot bahu

i) Gerakan 9

(1) Langkahkan kaki ke depan 1 langkah

(2) Kepalkan tangan dan simpan di dada 
(3) Tarik ke atas dan ke bawah

Gerakan 9 bermanfaat untuk melenturkan

persendian otot bahu dan punggung bagian atas

j) Gerakan 10

(1) Langkahkan kaki ke samping kanan dan kiri sebanyak 2 langkah

(2) Tangan direntangkan kedepan dan ke kanan atau kiri

(3) Gerakan kepala ke kanan dan ke kiri secara bergantian

Gerakan $\quad 10$

bermanfaat untuk

melenturkan

persendian otot bahu.

k) Gerakan 11

(1) Angkat tangan ke depan

(2) Satu kaki melangkah ke depan dan kaki yang lain mundur

(3) Lakukan secara brgantian

Gerakan 11 bermanfaat untuk menguatkan otot lengan

1) Gerakan 12

(1) Langkahkan kaki ke kanan dan ke kiri bergantian

(2) Kedua tangan membentuk sudut 90 derajat

Gerakan 12 bermanfaat untuk melatih koordinasi otot-otot lengan, bahu, dan kaki m) Gerakan 13

(1) Langkahkan kaki ke samping kanan dan kiri bergantian

(2) Bedua tangan simpan di depan

(3) Lakukan gerakan membuka dan menutup bergantian

Gerakan 13

bermanfaat untuk menguraikan otot dada dan bahu

n) Gerakan 14

(1) Posisi awal

(2) Kedua siku ditekuk dan telapan tangan mengepal di sisi pinggang

(3) Dorong kaki kanan dan kedua lengan ke belakang kemudian dilanjutkan dengan kaki kiri

Gerakan $\quad 14$ bermanfaat untuk melenturkan dan mengkoordinasikan persendian otot lengan dan paha bagian belakang

o) Gerakan 15

(1) Kaki tangan diangkat ke atas

(2) Kaki kanan serong ke kanan depan secara bergantian

Gerakan 15 bermanfaat untuk melenturkan dan mengkoordinasikan otot bahu, tangan dan tungkai

p) Gerakan 16

(1) Ayunkan kedua lengan bersamaan

(2) Tangan kanan lurus disisi bahu kanan 
sejajar dengan bahu dan tangan kiri lurus sejajar dengan bahu

(3) Kaki kanan diangkat kemudian seterusnya

Gerakan $\quad 16$

bermanfaat untuk melenturkan, mengkoordinasikan otot-otot bahu dan tubuh bagian atas serta lutut

q) Gerakan 17

(1) Tubuh kanan dicondongkan kearah kanan

(2) Tubuh kanan seperti menyentuh tumit kaki kanan

(3) Begitupun dengan sebelah kiri Gerakan 17 bermanfaat untuk merenggangkan lengan sisi tubuh dan paha bagian dalam

r) Gerakan 18

(1) Kaki dibuka

(2) Lutut sedikit ditekuk

(3) Ayunkan tangan kanan serong ke arah kiri

$\begin{array}{lr}\quad \text { Gerakan } & 18 \\ \text { bermanfaat } & \text { untuk } \\ \text { melenturkan } & \text { otot } \\ \text { kanan } & \end{array}$

s) Gerakan 19

(1) Kedua kaki terbuka

(2) Kedua tangan disamping kepala sejajar dengan bahu

(3) Putar sisi tubuh kearah kanan dan kiri bergantian

Gerakan 19

bermanfaat untuk melenturkan sisi tubuh

t) Gerakan 20
(1) Ayunkan lengan ke samping kiri dan kanan bergantian

(2) Kaki kiri dan kanan ditekung ke belakang Gerakan 20 bermanfaat untuk menguatkan otot-otot bahu dan tungkai serta koordinasi gerakan lenggan tungkai

u) Gerakan 21

(1) Kaki dibuka lebar, satu kaki melangkah ke depan

(2) Tekuk lutut kiri ke arah kanan

(3) Silahkan kedua tangan diatas kanan dan kiri Gerakan 19 bermanfaat melenturkan dan meregangkan otot-otot dan sendi, lengan bahu, sisi tubuh, pinggang dan tungkai

v) Gerakan 22

(1) Kaki kanan terbuka

(2) Tangan kanan tertumpu di paha kanan

(3) Tangan kiri lurus keatas

Gerakan 22 bermanfaat untuk meregangkan otot-otot paha dan tangan

w) Gerakan 23

(1) Tubuh menghadap ke kanan atau ke kiri

(2) Tangan lurus ke kanan atau ke kiri sejajar dengan bahu dan ditarik statis

Gerakan 23

bermanfaat untuk 
meregangkan otot lengan dan lutut

x) Gerakan 24

(1) Badan menghadap kanan dan kiri

(2) Tangan direntangkan ke atas

(3) Salah satu kaki ditarik ke belakang Gerakan 24 bermanfaat untuk melenturkan dan meregangkan otot-otot sendi, lengan bahu, sisi tubuh, pinggang dan tungkai

y) Gerakan 25

(1) Kaki kanan atau kiri menekuk ke depan

(2) Samping kanan dan kiri lurus ke belakang

(3) Kedua tangan bertumpu dipaha Gerakan 25

bermanfaat

meregangkan otot bahu, sendi punggung bagian atas

z) Gerakan 26

(1) Kaki kanan diluruskan

(2) Tangan kanan menyentuh ujung kaki kanan

(3) Lakukan bergantian Gerakan 26 bermanfaat untuk menguatkan sendi, bahu, punggung atas dan kaki

aa) Gerakan 27 dan 28

(1) Kaki kiri melangkah ke depan

(2) Kedua tangan diluruskan ke depan

(3) Ditarik ke belakang dan ditahan di depan dada disamping telinga

(4) Lakukan bergantian

Gerakan 27 dan

28 bermanfaat untuk meregangkan otot bahu, kaki, paha, dan punggung

bb) Gerakan 29

(1) Kaki kiri melangkah ke depan

(2) Kedua tangan tertumpu dikedua paha

(3) Lutut kanan ditekuk Gerakan 29 bermanfaat untuk meregangkan otot dinamis

cc) Gerakan 30 : sikap sempurna

b. Latihan inti

1) Tangan kanan lurus ke depan

2) Tangan kiri lurus ke depan

3) Tangan kanan lipat ke bahu kiri

4) Tangan kiri lipat ke bahu kanan

5) Telapak tangan kanan buka, di samping

6) telinga

7) Telapak kiri dibuka disamping telinga kiri Gerakan diatas dilakukan untuk mempersiapkan gerakan selanjutnya dan mengatur pernapasan

1) Inti 1
a) Badan tegak
b) Langkahkan kaki kanan ke depan 1 langkah
c) Kepalkan tangan angkat ke atas


d) Dengan hitungan angkat dan tarik tangan sejajar dengan bahu

Gerakan inti 1 bermanfaat untuk melenturkan tangan sebelum maju kegerakan selanjutnya.

2) Inti 2

a) Kaki melangkah ke depan

b) Tangan mengepal dan perut diangkat ke atas kepala

c) Lakukan seterusnya Gerakan inti 2 bermanfaat untuk menguatkan otot dada, lengan dan bahu

3) Inti 3

a) Tangan

kanan mengepal

b) Badan serong ke kanan

c) Kaki kiri membuka ke samping kiri

Gerakan inti 3 bermanfaat untuk menguatkan otot kaki dan pinggang

4) Inti 4 dan 5
a) Melangkah maju 1 langkah
b) Tangan mendorong ke depan
c) Mundur 1 langkah
d) Tangan dorong ke depan kemudian rentangkan ke atas
Gerakan inti 4 dan
5 bermanfaat untuk meningkatkan otot lengan, otot paha, dan otot dada

5) Inti 6
a) Kedua tangan mengepal kemudian tarik ke belakang
b) Kaki kanan melangkah ke depan
c) Lakukan secara bergantian dengan kaki kiri
Gerakan inti 6 bermanfaat untuk menguatkan otot tangan, bahu dan otot betis

6) Inti 7

a) Langkahkan ke depan kaki kiri

b) Tangan kiri direntangkan, tangan kanan simpan di dada

c) Kedua tangan mengayun ke kanan dan ke kiri

Gerakan inti 7 bermanfaat untuk melatih otot betis, otot paha, persendian lutut, dan lengan

7) Inti 8
a) Angkat kaki kiri ke belakang
b) Kedua tangan bentangkan ke depan
c) Lakukan bergantian dengan kaki kanan
Gerakan

8

bermanfaat untuk melatih keseimbangan, menguatkan otot betis, paha dan otot lengan

8) Inti 9
a) Buka kaki
b) Langkahkan ke depan kaki kanan dan kaki kiri mundur ke belakang
c) Telapak tangan di buka, tangan kiri bentangkan dan kanan simpan di dada


d) Ayunkan ke kanan dan kiri

9) Inti 10

a) Buka kaki

b) Langkahkan ke depan kaki kanan dan kaki kiri mundur ke belakang

c) Angkat kedua tangan keatas

Gerakan inti 9 dan 10 bermanfaat untuk melatih otot jari tangan, lengan, betis, dan paha

10) Inti 11

a) Buka kaki kiri ke samping kiri

b) Kedua tangan sejajar dengan dada

c) Rentangkan tangan ke bawah

d) Lakukan bergantian dengan kaki kanan

Gerakan inti 11 bermanfaat untuk melatih otot jari tangan, otot paha, dan otot bahu

11) Inti 12

a) Kaki kiri melangkah ke samping

b) Kedua tangan direntangkan sejajar dengan perut

Gerakan

12

bermanfaat untuk melatih otot jari tangan, otot bahu serta otot paha

12) Relaksasi 13

a) Tangan di depan dada

b) Rentangkan

bersamaan

melangkah ke

samping kanan dan

kiri

Gerakan 13 dan seterusnya masuk ke dalam relaksasi untuk penyegaran setelah melakukan pemanasan dan inti

13) Relaksasi 14

a) Kedua tangan direntangkan sejajar bahu dengan kedua tangan di kepal di dada

b) Kaki langkahkan ke kanan dan kiri

14) Relaksasi 15

a) Kedua tangan mengayun ke atas

b) Kaki langkahkan ke kanan dan kiri

15) Relaksasi 16

c. Pendinginan

a) Sikap sempurna

1) Pendinginan 1

a) Langkahkan kaki kiri ke samping

b) Lutut kiri ditekuk

c) Kedua lengan direntangkan

d) Kepala ditundukkan Gerakan tersebut bermanfaat untuk relaksasi pernapasan dengan gerakan tangan dan kaki

2) Pendinginan 2

a) Kaki kanan di buka

b) Lengan di depan dada

c) Tubuh ditarik ke arah kanan dan ditahan beberapa detik

Gerakan pendinginan

2 bermanfaat untuk merelaksasi kembali otototot tubuh

3) Pendinginan 3
a) Kaki
kanan
melangkah ke depan
b) Tangan dibentangkan 
Gerakan pendinginan 3 bermanfaat untuk relaksasi pernapasan

4) Pendinginan 4

a) Kaki kiri maju ke depan

b) Lutut ditekuk

c) Kedua lengan direntangkan ke depan

d) Telapak tangan menghadap ke dalam Gerakan pendinginan 4 bermanfaat untuk merelaksasikan otot bahu, kaki, paha dan punggung

5) Pendinginan 5

a) Kaki kiri di depan

b) Tangan kiri dibentangkan ke belakang, tangan kanan menjadi penyanggah

Gerakan pendinginan 5 bermanfaat untuk merelaksasikan otot lengan bahu

6) Pendinginan 6

a) Kaki kiri maju ke depan

b) Kaki kanan ke belakang

c) Kedua tangan bertumpu di paha

Gerakan pendinginan

6 bermanfaat untuk merelaksasikan otot bahu, sendi dan punggung

7) Pendinginan 7

a) Kaki dibuka di samping

b) Tangan kanan menarik sikut kiri ke arah belakang

Gerakan pendinginan

7 bermanfaat untuk merelaksasikan otot bahu dan tubuh bagian belakang
8) Pendinginan 8

a) Menghadap ke kanan

b) Kaki kanan tekuk dan kaki kiri lurus

c) Kedua tangan lurus menghadap kanan

Gerakan pendinginan 8 bermanfaat untuk merelaksasikan kaki dan badan

9) Pendinginan 9

a) Menghadap ke kanan

b) Kaki kiri jinjit

c) Kaki kanan lurus dan kedua lengan ke atas

Gerakan pendinginan

9 bermanfaat untuk merelaksasikan pertegangan kaki dan punggung

10) Pendinginan 10

a) Kaki kiri tarik ke belakang

b) Kaki kanan tekuk

c) Kedua tangan bertumpuk di kaki kanan

Gerakan pendinginan 10 bermanfaat untuk merelaksasikan kaki dan badan

11) Pendinginan 11

a) Mengadap ke kanan

b) Rentangkan tangan kanan seperti menyentuh ujung kaki kiri

c) Kaki kiri ditekukan, kaki kanan lurus sejajar dengan tangan Gerakan pendinginan 11 bermanfaat untuk menguatkan otot paha dan tumit

12) Pendinginan 12
a) Kaki kanan melangkah ke samping 
b) Kedua lengan direntangkan ke samping

c) Kedua lutut ditekuk sedikit

Gerakan pendinginan

12 bermanfaat untuk relaksasi peregangan dengan gerakan tangan dan lutut.

13) Pendinginan 13 : sikap sempurna (Novitasari, 2012)

17. Pengaruh Senam Diabetes Terhadap Penyakit Diabetes Mellitus Tipe 2

Khoirul (2013) dengan judul Perbedaan Kadar Gula Darah Sebelum dan Sesudah Senam Diabetes Pada Pasien Diabetes Mellitus Tipe 2 di Persadia Rumah Sakit Asih Ciputat Tahun 2013. Hasil penelitian menunjukkan bahwa ada perbedaan kadar gula darah sebelum dan sesudah senam diabetes pada pasien diabetes mellitus tipe $2(\mathrm{p}=0,048)$.

Mulyaningtyas (2012) dengan judulPengaruh Senam Terhadap Kadar Gula Darah Penderita Diabetes.Hasil dari penelitian ini terdapat perbedaan kadar gula darah sewaktu sebelum dan sesudah intervensi pada kelompok terpapar (nilai $\mathrm{p}$ $=0,0001)$, pada kelompok tidak terpapar (nilai $\mathrm{p}=0,0001$ ), pada kelompok terpapar dan tidak terpapar (nilai $\mathrm{p}=0,0001$ ) dengan penurunan rata-rata gula darah pada kelompok terpapar 2,3 kali lebih besar daripada kelompok tidak terpapar $(31,5$ $\mathrm{mg} / \mathrm{dl}$ berbanding 13,5 $\mathrm{mg} / \mathrm{dl}$ ). Kesimpulan yang dapat diambil adalah senam efektif dalam menurunkan kadar gula darah.

Perbedaan penelitian ini dengan penelitian sebelumnya adalah dalam penelitian ini samplingnya di batasi oleh beberapa lama seseorang menderita Diabetes Melitus Tipe 2 dimana pada penelitian sebelumnya hal ini tidak menjadi kriteria.

\section{A. Kerangka Teori}

Kerangka teori adalah kemampuan seorang peneliti dalam mengaplikasikan pola berfikir dalam menyusun teori-teori secara skematis yang mendukung permasalahan. Menurut Karlinger, teori adalah himpunan konstruk (konsep), definisi, dan proposisi yang mengutamakan pandangan sistematis tentang gejala dengan menjabarkan relasi diantara variabel, untuk menjelaskan dan meramalkan gejala tersebut (Rakhmat, 2006).

Atas dasar kajian kepustakaan tentang senam yang secara hipotesis berpengaruh terhadap kadar gula darah pada penderita diabetes mellitus tipe 2, maka ditunjukan kerangka teori pada skema 2.1 sebagai berikut

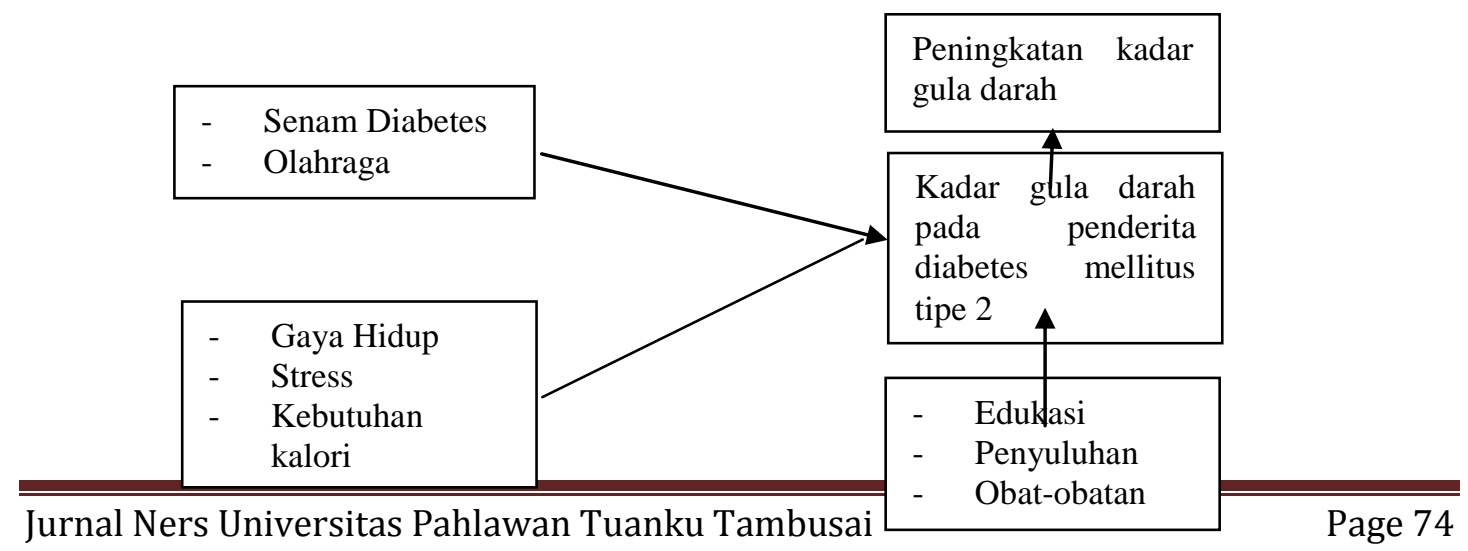




\section{Skema 2.2 \\ Kerangka Teori \\ Pengaruh Senam Terhadap Kadar Gula Darah Pada Penderita Diabetes Mellitus Tipe 2 Di RSUD Puri Husada Tembilahan Tahun 2016}

\section{B. Kerangka Konsep}

Kerangka konsep merupakan suatu hubungan atau kaitan antara konsep satu terhadap konsep yang lainnya dari masalah yang ingin diteliti (Setiadi, 2013). Dengan demikian kerangka konsep sebagai berikut:

Variabel Independen $t$

Kadar Gula Darah Pada Penderita Diabetes Mellitus Tipe 2 sebelum diberikan Diabetes

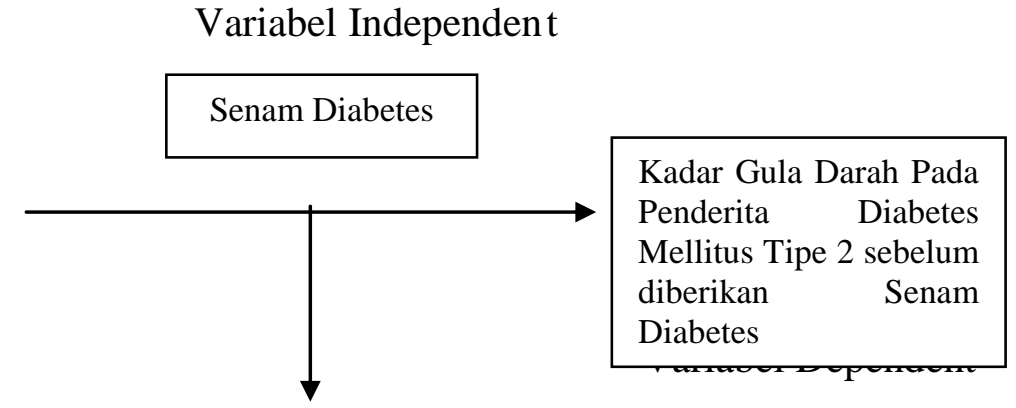

Skema 2.3

Kerangka Konsep

Pengaruh Senam Terhadap Kadar Gula Darah Pada Penderita Diabetes Mellitus Tipe 2 Di RSUD Puri Husada Tembilahan Tahun 2016

\section{Hipotesis}

$\mathrm{H}_{\mathrm{a}}$ : Ada pengaruh senam diabetes terhadap kadar gula darah pada penderita diabetes mellitus tipe 2

\section{BAB IV}

\section{HASIL PENELITIAN}

Penelitian ini bertujuan untuk menganalisis Pengaruh Senam Terhadap Kadar Gula Darah Pada Penderita Diabetes Mellitus Tipe 2 Di RSUD Puri Husada Tembilahan Tahun 2016. Pengumpulan data pada penelitian ini dimulai dari9 s/d 21 Mei 2016. Pada bab ini akan diuraikan hasil penelitian setiap variabel melalui analisis univariat dan bivariat.

\section{A. Analisis Univariat}

Analisis univariat pada penelitian ini dilakukan untuk mengetahui mean, median, simpangan baku (SD), nilai minimal dan maksimal kadar gula darah pada penderita diabetes mellitus tipe 2 sebelum dan sesudah melakukan senam diabetes di RSUD Puri Husada Tembilahan Tahun 2016. Masing-masing variabel pada penelitian ini dapat dilihat pada tabel di bawah ini :

Tabel 4.1 : Kadar Gula Darah Pada Penderita Diabetes Mellitus Tipe 2 Sebelum Dan Sesudah Melakukan Senam Diabetes Di RSUD Puri Husada Tembilahan Tahun 2016.

\begin{tabular}{lccc}
\hline Variabel & Mean & Standar Deviasi & Min-Max \\
\hline Kadar Gula Darah & & & \\
\hline
\end{tabular}




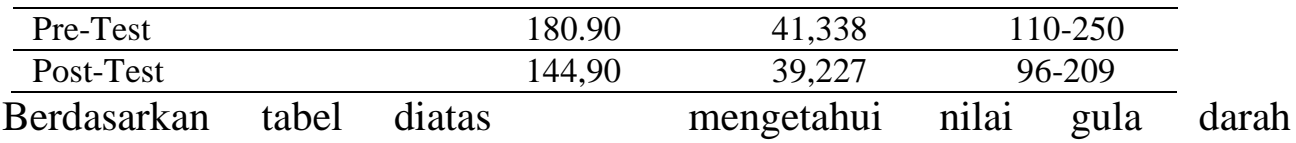

dapat menggambarkan bahwa terdapat penurunan kadar gula darah sebelum dan sesudah melakukan senam diabetes. Hal ini dapat dilihat dari rata-rata kadar gula darah sebelum melakukan senam diabetes sebesar 180,90 $\mathrm{mg} / \mathrm{dl}$ sedangkan rata-rata kadar gula darah sesudah melakukan senam 144,90 mg/dl.

\section{B. Analisis Bivariat}

Analisis bivariat akan menguraikan perbedaan penurunan kadar gula darah dengan

Tabel 4.2 : Pengaruh Senam Diabetes Terhadap Kadar Gula Darah Pada Penderita Diabetes Mellitus Tipe 2 Di RSUD Puri Husada Tembilahan Tahun 2016 $\mathbf{n}=\mathbf{2 0}$

\begin{tabular}{|c|c|c|c|c|c|}
\hline Variabel & $\begin{array}{c}\text { Jumlah } \\
\text { Observasi }\end{array}$ & $\begin{array}{l}\text { Mean } \\
\text { Rank }\end{array}$ & $\begin{array}{l}\text { Sum of } \\
\text { Ranks }\end{array}$ & CI $95 \%$ & P Value \\
\hline $\begin{array}{l}\text { Kadar Gula Darah } \\
\text { Negatif Rank }\end{array}$ & 18 & 11,11 & 200,00 & $0,000-0,139$ & 0,000 \\
\hline Positif Rank & 2 & 5,00 & 10,00 & & \\
\hline
\end{tabular}
kemaknaan 95\% atau alpha 0,05. Masing-masing analisis variabel pada penelitian ini dapat dilihat pada tabel di bawah ini : sebelum dan sesudah perlakuan senam diabetes selama 2 minggu. Pada penelitian ini Analisis bivariat dilakukan dengan uji Wilcoxon karena uji statistik sampel t-test (paired t-test) atau uji beda dua mean dependen tidak memenuhi asumsi normalitas. Uji statistik untuk seluruh analisis tersebut dianalisis dengan tingkat

(posttest) lebih rendah dari nilai variabel pertama (pretest) jumlah observasinya sebanyak 18 observasi, dengan nilai mean 11,11 dan jumlah nilai rata-rata 200, sedangkan positif ranks atau nilai variabel kedua (posttest) lebih tinggi dari nilai variabel pertama (pretest) jumlah observasinya sebanyak 2 observasi dengan nilai mean 5 dan jumlah nilai rata-rata 10 . Data tersebut menggambarkan adanya perbedaan kadar gula darah pasien diabetes mellitus tipe 2 sebelum dan sesudah senam diabetes, dan juga menunjukkan adanya pengaruh antara senam diabetes terhadap penurunan kadar gula darah pasien diabetes mellitus tipe 2. Dari hasil uji statistik didapatkan nilai $\mathrm{p}$ value 0,000, dapat disimpulkan bahwa

\section{BAB V \\ PEMBAHASAN}

\section{A. Pengaruh Senam Diabetes Terhadap Kadar Gula Darah Pada Penderita Diabetes Mellitus Tipe 2 Di RSUD Puri Husada Tembilahan Tahun 2016}

Berdasarkan hasil distribusi kadar gula darah pada penelitian saya dapat disimpulkan bahwa terdapat beda rata-rata kadar gula darah sebelum dan sesudah dilakukan senam diabetes selama 2 minggu dimana kriteria responden salah satunya yang menderita 
diabetes mellitus tipe 2 selama 1 5 tahun.

Hasil analisa statistik dari sebelum senam diabetes yaitu pada minggu pertama sampai setelah senam diabetes pada minggu ke 2 menunjukkan adanya perubahan kadar gula darah saat dilakukan test pada peserta senam diabetes. Didapatkan nilai rata-rata kadar gula darah pre-test sebesar 180,90 dengan standar deviasi 41,338 dan rata-rata kadar gula darah post-test 144,90 dengan standar deviasi $39,227$.

Hasil analisis uji wilcoxon pada negative ranks atau nilai posttest lebih rendah dari nilai pretestsebanyak 18 observasi dengan nilai mean 11,11 dan jumlah rata-rata 200, sedangkan positif ranks atau nilai posttest lebih tinggi dari nilai pretest ada 2 observasi dengan nilai mean 5 dan jumlah rata-rata 10 . Data tersebut menggambarkan adanya perbedaan kadar gula darah pasien diabetes mellitus tipe 2 sebelum dan sesudah senam diabetes, dan juga menunjukkan adanya pengaruh antara senam diabetes terhadap penurunan kadar gula darah pasien diabetes mellitus tipe 2. Dari hasil uji statistik didapatkan nilai $\mathrm{p}$ value 0,000,sehingga dapat disimpulkan bahwa terdapat pengaruh kadar gula darah pasien diabetes mellitus tipe 2 sebelum dan sesudah senam diabetes di RSUD Puri Husada.

Pada penelitian yang dilakukan oleh Puji Indriani, Heru Supriyatni dan Agus Santoso yang menunjukkan bahwa ada pengaruh latihan fisik, senam aerobik terhadap penurunan kadar gula darah pada penderita diabetes mellitus tipe 2 di Wilayah Kerja Puskesmas Bukateja Purbalingga pada tahun 2004. Jenis penelitian ini merupakan penelitian pra eksperimen tanpa kelompok kontrol dengan $p$ value 0,001

Gula darah adalah produk akhir dan merupakan sumber energi utama organisme hidup yang kegunaannya dikontrol oleh insulin. Umumnya tingkat gula darah bertahan pada batas-batas yang sempit sepanjang hari 4-8 $\mathrm{mmol} / \mathrm{I}$ (70-150 $\mathrm{mg} / \mathrm{dL})$. Tingkat ini meningkat setelah makan dan biasanya berada pada level terendah pada pagi hari, sebelum makan. Pada pasien diabetes mellitus adalah penyakit yang paling menonjol yang disebabkan oleh gagalnya pengaturan kadar gula darah, selain glukosa, juga menemukan jenis-jenis gula lainnya seperti fruktosa dan galaktosa. Pada diabetes mellitus tipe 2 tidak tergantung insulin, latihan (senam diabetes) sangat baik untuk pengendalian kadar gula darah sehingga menghambat risiko penyakit yang muncul dari komplikasi diabetes mellitus.

Keikutsertaan dalam senam diabetes didasari oleh berbagai alasan antara lain kesadaran pasien untuk meningkatkan kesehatan dan mengontrol gula darah, mengisi kesibukan dan anjuran dokter. Banyak responden belum mengikuti senam diabetes, hal ini dipengaruhi oleh beberapa faktor, antara lain faktor pengetahuan atau persepsi terhadap penanganan dan perawatan diabetes, motivasi diri, dan informasi.

Menurut Ilyas (2009) latihan jasmani secara langsung dapat 
menyebabkan terjadinya peningkatan pemakaian glukos sehingga lebih banyak tersedia reseptor insulin dan reseptor insulin menjadi lebih aktif yang akan berpengaruh terhadap penurunan glukosa darah pada pasien diabetes mellitus sehingga terjadi perubahan pada kadar gula darah.

Menurut Soekardji (2009) latihan jasmani pada diabetes mellitus tipe 2 berperan utama dalam pengaturan kadar gula darah. Pada tipe ini produksi insulin umumnya tidak terganggu. Masalah utama adalah kurangnya respons reseptor insulin terhadap insulin, sehingga insulin tidak dapat masuk ke dalam sel-sel tubuh kecuali otak. Otot yang berkontraksi atau aktif tidak memerlukan insulin untuk memasukkan glukosa ke dalam sel otot yang aktif sensitivitas reseptor insulin meningkat. Oleh karena itu latihan jasmani pada diabetes mellitus tipe 2 akan menyebabkan berkurangnya kebutuhan insulin eksogen. Namun ini tidak bertahan lama oleh karena itu dibutuhkan latihan jasmani yang kontinu dan teratur. Karena bermanfaat terhadap perubahan kadar gula darah menjadi menurun dan lebih terkontrol.

Berdasarkan hasil penelitian dan uraian diatas dapat disimpulkan bahwa kadar gula darah pada pasien diabetes mellitus tipe 2 dapat dikendalikan dengan melakukan latihan jasmani (senam diabetes) secara teratur dan kontinu karena pada saat istirahat ambilan glukosa oleh otot jaringan membutuhakan insulin sedangkan pada otot aktif walaupun terjadi peningkatan kebutuhan glukosa tetapi kadar insulin tidak meningkat. Hal ini disebabkan karena peningkatan kepekaan reseptor insulin otot dan pertambahan reseptor insulin otot pada saat melakukan senam.

\section{BAB VI PENUTUP}

\section{A. Simpulan}

Berdasarkan hasil penelitian dan pembahasan yang telah diuraikan dalam bab sebelumnya, makadapat disimpulkan bahwa terdapat pengaruhsenam diabetes terhadap kadar gula darah pada penderita diabetes mellitus tipe 2 di RSUD Puri HusadaTembilahanTahun 2016.

\section{B. Saran}

Berdasarkan kesimpulan yang telah dibuat ada beberapa saran yang ingin disampaikan oleh peneliti yaitu:

1. Untuk Peneliti Selanjutnya

Diharapkan kepada peneliti selanjutnya agar dapat melakukan penelitian dengan kajian yang sama dengan waktu yang lebih lama, sehingga pelaksanaan senam yang diberikan lebih bermanfaat bagi penderita diabetes mellitus.

2. Untuk Tempat Penelitian

a. Diharapkan kepada pimpinan RSUD Puri Husada dan selingkungan RSUD Puri Husada agar selalu memberikan penyuluhanpenyuluhan terhadap penyakit diabetes mellitus

b. Diharapkan kepada instruktur senam diabetes agar lebih memperhatikan penderita diabetes di RSUD Puri Husada dengan menambah waktu latihan terhadap penderita diabetes mellitus 
untuk melakukan kegiatan senam diabetes.

\section{DAFTAR PUSTAKA}

Anani, Sri. (2012). Diabetes (Hiperglikemia).

http://www.detik.com /indo/news.php?n=11. Diakses 19 Maret 2016

Anggriyana.(2010). Diabetes and exercise.http://www.uhs.wisc.edu/ docs/uwhealth_diabetes_260.pdf. Diakses 19 Maret 2016

Arikunto. (2010). Prosedur Penelitian Suatu Pendekatan Praktik. Jakarta : PT Rineka Cipta

Arisman. (2010). Obesitas, Diabetes Mellitus \& Dislipidemia. Jakarta : EGC

Erlina, Lina (2008). Pengaruh Senam Diabetes Terhadap Kadar Glukosa Darah Pasien DM Tipe 2 Di RSU Unit Swadana Daerah Kabupaten Sumedang. Bandung.

Ernawati. (2013). Penatalaksanaan Keperawatan Diabetes Mellitus Terpadu. Jakarta : Mitra Wacana Media

Hidayat, Aziz Alimul. (2014). Riset Keperawatan dan Tehnik Penelitian Ilmiah. Jakarta: Salemba Medika

Ilyas, E.I. (2009). Olahraga bagi diabetes. Jakarta : FKUI

Khoirul. (2013). Perbedaan Kadar Gula Darah Sebelum dan Sesudah Senam Diabetes Pada Pasien Diabetes Mellitus Tipe 2 di Persadia Rumah Sakit Asih Ciputat Tahun 2013.
Kumar. (2007). Mencegah komplikasi penyakit kencing manis. http://www.sinar harapan.konsultasi/htm. Diakses 19 Maret 2016

Mulyaningtyas. (2012). Pengaruh Senam Terhadap Kadar Gula Darah Penderita Diabetes. Semarang

Novitasari, Retno. (2012). Diabetes Mellitus. Yogyakarta : Nuha Medika

Nursalam. (2013). Metodologi Penelitian Ilmu Keperawatan. Jakarta : Salemba Medika

Padila. (2012). Senam Diabetes Seri 3. Jakarta: Yayasan Diabetes Indonesia

Profil Rumah Sakit Umum Daerah Puri Husada Tembilahan (2016)

Saryono (2010). Kumpulan Instrumen Penelitian Kesehatan. Bantul : Nuha Medika

Saryono dan Ari Setiawan. (2010). Metodologi Penelitian. Yogyakarta : Nuha Medika

Setiadi. (2013). Konsep dan Praktik Penulisan Riset Keperawatan. Yogyakarta : Graha Ilmu

Soegondo, dkk. (2015). Penatalaksanaan Diabetes Mellitus Terpadu. Jakarta : FKUI

Sudiro. (2014). Diabetes Informasi Lengkap Untuk Penderita dan Keluarganya. Jakarta: Gramedia

Sudoyo, dkk. (2007). Buku Ajar Ilmu Penyakit Dalam. Jakarta : FKUI 
Sumarni. (2008). Epidemiologi Penyakit Tidak Menular. Jakarta: PT Rineka Cipta

Sigiyono. (2011). Metode Penelitian Kombinasi. Bandung : Alfabeta

Titin. (2010). Segala Sesuiatu yang Harus Anda Ketahui Tentang Diabetes. Jakarta: Gramedia

Wylie, Linda. (2010). Gangguan Medis Kehamilan \& Persalinan. Jakarta : EGC 